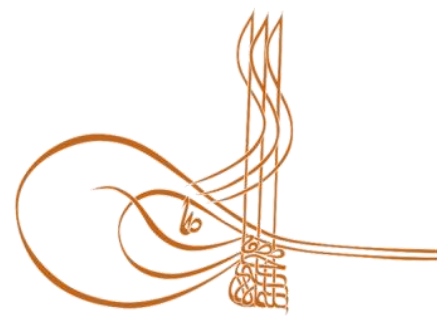

www.turkishstudies.net/economy
Turkish Studies - Economics, Finance, Politics

eISSN: $2667-5625$

Research Article / Araștırma Makalesi

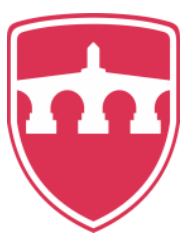

INTERNATIONAL BALKAN

UNIVERSITY

Sponsored by IBU

\title{
Bir Başarı Hikâyesi Olarak 1970’ler CHP Belediyeciliğinin Anlamı Üzerine
}

\author{
As A Success Story on the Meaning of the 1970's Chp Municipality
}

\author{
Cihan Palanc1*
}

\begin{abstract}
With the emergence of the urban phenomenon in Turkey is developed in the domestic politics of the policy conditional funding and overall control of the central government. It took time for an autonomous understanding of municipality to settle and the fact that urban discipline had an independent trajectory was faced quite late. However, it is an obvious fact that political practices, which started at the local level and where meeting with the public took place without any preconditions, also directed central politics after a while. In this sense, Turkey's general elections in 1977 is a good example. In the period between 1973 and 1977, the dynamism caught with the successful municipality of the CHP found its worth in the general elections and the CHP came out of the ballot box with a rate of 41 percent. In the background of this success; The CHP has also partially changed the party ontology of the past, turning its face from the middle-class urbanists to the working class, who came through migration, in poverty, who could not benefit from the city facilities sufficiently. The study program that provides full local this ontological transformation, namely "socialist municipality" examine what is conceptualized as a theoretical whole, in particular CHP, Turkey will seek answers to the question what he did right. While looking for these answers, we will also examine how dynamics of local governments and local politics have developed in the world, and we will try to answer questions such as what demands of society respond to the changes experienced by cities. In parallel, the changes related to the city in our country and the demands of the society for urban administrations will be compared with the urban movements and demands in the west and efforts will be made to clarify the parallels and differences in this sense.
\end{abstract}

Structured Abstract: Urban movements and urban development in Europe are both very dynamic and highly correlated with total political transformations. With the 19th century, as capitalism was now the dominant mode of production, radical demands and transformation took place, especially in large and industrialized cities in Europe. The essence of this transformation is that the concentrated areas are both in terms of infrastructure and the old style of municipalism and the management style not being able to adapt to the new situation. The pain of the transformation of the urban buildings of the period into industrial cities is important as it is the feudal city prototype where these cities are located, and the dominant mode of production of feudal cities. The modern city is a static city, it is shaped by constant contradictions and conflicts, and writes as modern city practices and theories are. According to him, an exit point is required to present and present the "urban problem", which

\footnotetext{
* Dr. Öğr. Gör., Munzur Üniversitesi, Pertek Sakine Genç Meslek Yüksekokulu, Finans Bankacılık ve Sigortacılık Bölümü Dr. Lecturer, Munzur University, Pertek Sakine Genç Vocational School, Finance Banking and İnsurance Department ORCID 0000-0001-6766-3691 cihanp44@gmail.com

Cite as/ Atıf: Palancı, C. (2020). Bir başarı hikâyesi olarak 1970’ler Chp belediyeciliğinin anlamı üzerine, Turkish Studies - Economy, 15(1), 481-490. https://dx.doi.org/10.29228/TurkishStudies.41633

Received/Geliş: 05 February/Şubat 2020

Accepted/Kabul: 25 March/Mart 2020

Copyright $@$ INTAC LTD, Turkey
} 
is for industrialization. From the beginning of industrialization, Lefebvre emphasizes that the old order and the mode of production are frozen the cities and the new city requirement of the bourgeoisie is the most important area of conflict between these two major actors. Lefebvre ranks due to these conflicts:

-Conflict between use value and exchange value,

-The unproductive investment conflict in the city by mobilizing wealth as money and valuable paper,

-Conflict between capital accumulation and capital wasting in festivities,

-Conflict between the expansion of the sovereign territory and the necessity of strict organization of these soils in the dominant city environment (Lefebvre, 2016: 21-24).

The second most important wave of urban movement in Europe is the 1968 movement. The main demand of the 1968 movement can be described as freedom in the city, so the 1968 urban movement can be considered for protesting the state's spatial orientation and domination mechanisms over the city and the city. The destruction after the 2nd World War, together with a different economic paradigm, paved the way for the state to actively participate in all areas of life and the economy, and with the enrichment created, the welfare state practices made itself felt in every capillary of the city. In the west, the local government has positioned itself as an intermediary for the distribution of prosperity to the city in accordance with the central state. However, Fordist production style and welfare state practices that existed after the mid-1960s started to enter the crisis and be criticized. Basically criticized point is the internal contradictions of the Fordist-capitalist mode of production and the context of the general conjuncture of the world. It is inevitable to establish the relationship between this standardization and capitalism, which manifests itself in all areas of life. But this relationship is not unique to those who practice capitalism. In the continental Europe of the period, the opposition thinkers who worked on it, deciphered and ultimately directed the masses were quite and active. Harvey makes use of Lefebvre for this, arguing: "In monetary economies and in capitalism in particular, money crosses over time and space, an intrinsic connection of social power that we cannot ignore." Harvey adds; "Those who define the meaning of this trio actually define the basic rules of social play" (Harvey, 2003: 255).

In Turkey, the urbanization process in the European context, both at a theoretical level compared to urban policy and demand are fairly new. The intense migration movement, which started especially in the 1960s, could not be met with cold blood by policy makers who had not experienced a certain urbanization experience and crisis before. Moreover, the country's theoretical and theoretical knowledge is also inadequate. In this sense until the 1970s in Turkey, which is generally representative of the middle-class and the dominant ideology of the CHP, has changed the political trajectory of the movement and dynamism of urbanization experienced in his face and returned to the working classes. With the socialist municipalism policies it implemented, it regained these municipalities again in the following period and brought its party to power thanks to the right policies implemented there. In this process, one of the most important things that the CHP municipalities did was to ensure the democratization of the city administration. Until then, the practice of municipalism, which continued with the hegemony of certain interest groups, was reversed with the understanding of socialist municipality. 73-77 experience with CHP has shown us; when the right local policies are made available to the public, despite all the deprivations, these policies definitely find a response in the public. By all deprivations, we mean not only the budget, but also all kinds of deprivation in the sense of theoretical and practical accumulation for local governments at that time. As it is seen in the review, until the $70 \mathrm{~s}$ in Europe, municipality and city problem has taken important steps, thanks to this, both theoretical, managerial and technical accumulation has occurred. With the 1968 movement, the issues related to the city were discussed in a concrete way on the ground of freedom problem as well as the correct transfer of public resources and caused public authorities to take concrete steps. However, the process of city and municipalism is quite new in us. Moreover, the municipalism of the period is mostly referred to by individuals, so the urban demands of the period we examined are the demands that Europe has already made long ago but have not been realized yet. In this sense, the reflections of the 1968 movement in Europe to the demands of the city in our country are mostly moral. However, this process into practice in order to meet the basic needs of urban Turkey, especially in big cities have been read correctly and in a manner that can not be denied kamuc has been one of the most important projections could be called in front of the municipality.

Keywords: Chp, Municipality, Urbanization, Urbanization in Europe

Turkish Studies - Economy, 15(1) 
Öz: Türkiye'de kent olgusunun ortaya çıkışıyla birlikte, yerel siyasetin politikalanı genel olarak merkezi hükümetlerin koşullu finansmanı ve kontrolünde gelişmiş̧ir. Özerk bir belediyecilik anlayışının yerleşmesi zaman almış ve kent disiplininin bağımsız bir yörüngesi olduğu gerçeği ile oldukça geç yüzleşilmiştir. Bununla birlikte yerelde başlayan ve halkla buluşmanın ön koşulsuz gerçekleştiği siyasi pratiklerin, bir süre sonra merkezi siyasete de yön verdiği açık bir gerçektir. Bu anlamda 1977 Türkiye genel seçimleri buna güzel bir örnektir. 1973-1977 arası dönemde, CHP'nin başarılı belediyeciliği ile yakalanan dinamizm, genel seçimlerde karşılığını bulmuş ve CHP, yüzde 41 gibi bir oy oranı ile sandıktan çıkmıştır. Bu başarının geri planında; CHP'nin geçmişteki parti ontolojisini de kısmen değiştirerek, yüzünü orta sınıf kentlilerinden, göçle gelen, yoksulluk içinde, kent imkânlarından yeterince yararlanamayan emekçi sınıfa dönmesi vardır. Çalışma, tam da bu ontolojik dönüşümü sağlayan yerel programı, yani “Toplumcu Belediyecilik" olarak kavramsallaştırılan teorik bütünün ne olduğunu inceleyip, CHP'nin Türkiye özelinde neleri doğru yaptığı sorusunun cevaplarını araştıracaktır. Bu cevaplar aranırken aynı zamanda dünyada yerel yönetimlerin ve yerel siyasetin hangi dinamiklerle nasıl geliştiği de incelenecek ve kentlerin yaşadığı değişimlerin toplumun hangi taleplerine karşılık verdiği gibi soruları cevaplamaya çalışılacağız. Paralel olarak ülkemizde kent ile ilgili değişimlerin ve toplumun kent yönetimlerine yönelik taleplerinin, batıdaki kent hareketleri ve talepleri ile karşılıştırılması yapılacak ve bu anlamdaki paralellikler ve ayrımlar netleştirilmeye çalışılacaktır.

Anahtar Kelimeler: Chp, Belediyecilik, Kentleşme, Avrupa'da Kentleşme

\section{Giriş}

Habermas (2017) ideal kamusal alanı özetle; insanların özgürce bir araya geldiği ve devlet ya da piyasa baskısı olmadan serbestçe konuştuğu, tartıştı̆̆ı, örgütlendiği yerler olarak tarif eder. Yine Habermas'a göre bu ideal kamusal alan 18.yy'da yaşanmış ve bitmiştir. Bu bitişin kapitalizmin, modern devletle birlikte kurumsallaştı̆̆ döneme denk gelmesi tesadüf değil. Kentlerde insanların bir araya gelmesi, kurdukları ilişki ağları, sistem için hep bir tehdit unsuru olarak algılanmış, her dönem engellenmeye çalışılmış ve bunun için birçok mekanizma işletilmiştir. Örneğin Bumin (2016: 103), 1800'lerin son döneminde, Fransa'da konut sorununa çözüm yolları aranırken, yetkililerin, işçilere tahsis edilecek evlerin küçük bir arka bahçesi olması şartını, işçilerin iş çıkışı buluşma yerlerine gitmeden eve gidip küçük bahçelerinde oyalanma gibi bir niyetle koyduklarını anlatır. Onları olabildiğince sokaktan uzak tutmak ve evlerine hapsetmek burada temel hedeftir. Modern kentlerin de artık birer sermaye nesnesine dönüştüğü günümüzde, aynı mantıkla birçok kamusal alan mekânı, bir rant heyulasıyla kapitalizme kurban ediliyor. İleride ayrıntılandırılacağı gibi özellikle Avrupa'da kent hareketlerinin geri planındaki tartışmalar, modernizm-postmodernizm sahnesinde yapılmış ve post-yapısalcı düşünürlerin neredeyse toptan bir yıkıcılık ve yok sayma üslubuyla gerçekleştirdikleri modernizm eleştirileri, eksikliklerine rağmen önemli kazanımlarının dikkate alınması gerektiği savunması ile göğüslenmeye çalışılmıştır. Örneğin Habermas'ın genel yaklaşımı, modernizmin geldiği son noktanın eleştirilmesi gerektiğini fakat modernizmin diyalektik gelişen bir süreç olduğunu ve postmodernizmin de modernizm içinden doğan bir karşı çıkış olarak yine aynı yere döneceğini belirtir. Habermas'ın siyasal önerisi, tüm farklılıkları içine alan, ulus ve milliyet merkezli vatandaşl1k yerine, "anayasal yurttaşl1k" ile tüm siyasal öznelerin kamusal alana taşınmasıdır. Bu da aslında karşı eleştiri sahipleriyle çok uyumsuz bir öneri değildir. Foucault’un Heterotopia'sı ile Habermas'ın kamusal alanı farklı yerlerde duran iki düşünür için bu anlamda benzerlikler arz eder. Sonuç olarak mikro siyaset ve teori tartışmalarının ötesinde kapitalist yıkımın karşısında durabilmek ve geçmiş̧in kazanım ve birikimlerini tekrardan hatırlamak biz kent mağdurları için oldukça önemli. Özellikle ülkemizdeki gibi, kentleşme evrimi ve birikimi yeni yeni oluşan yerlerde, zaten az olan kent deneyimlerini doğru değerlendirmek ve alana yansitmak, kent tartışmalarının merkezinde yer almalı. Bu anlamda çalışma, bu birikimi aktarmak ve aktarırken de akademik olarak bir model ile beraber sunmak gibi bir niyet içeriyor. 


\section{Kentleşme Ve Toplumcu Belediyeciliğin Batıdaki Gelişimi}

Belediyecilik üzerine tartışırken kavramın çıkış noktası üzerine yapılacak referanslar önemlidir. Çünkü tarihi 19.yy'a kadar giden toplumcu belediyecilik uygulamaları çekirdek itibariyle aslında pek de değişmemiş ve örneğin 1970'lerdeki yeni akıma ilham ve referans olmuştur. 1871'de yaşanan Paris Komünü deneyimi, toplumcu belediyeciliğin ilk örneklerinden biridir. Paris Komünü 'nün tetikleyicisi olan kentsel sorunlar ve bu sorunlara bulunan çözüm yolları üzerinden 100 küsur yıl geçmesine rağmen halen tartışılmakta ve önemli bir kesim tarafından halen çözüm anahtarı olarak sunulmaktadır. Güler'in altını çizdiği gibi komün; Paris halkı tarafından hiçbir yardım görmeden kamu hizmetlerinin görülmesine yönelik gerçekleştirilmiş devrimci bir harekettir (Güler, 2013: 127). Komün sürecine gelene kadar Avrupa'da yaşanan sanayileşme önemlidir ve bize aslında olacakları önceden haber veren bir projeksiyondur. Yaşanan dönüşümün kentlerde bir kriz ile karş1lı bulacağını ve geleneksel orta çağ kentlerinin dinamiklerinin bu dönüşümün önünde duramayacağını belirtmek gerekir. Lefebvre şehir kavramının sanayileşme öncesinde de var olduğunu ama sanayileşmeyle birlikte modern anlamda statik olan şehrin sürekli çelişki ve çatışmalarla şekillenerek modern şehir pratiklerinin ve kuramlarının oluştuğunu ayrıntılı olarak yazar. Ona göre "Kent sorunsalını" sunmak ve ortaya koymak için bir çıkış noktası gerekir, bu da sanayileşme sürecidir. Lefebvre sanayileşmenin başlangıç aşamasından itibaren, eski düzen ve üretim biçiminin kentleri donuklaştırdığını ve burjuvazinin yeni şehir gereksiniminin bu iki başat aktör arasındaki en önemli çatışma alanı olduğunu vurgular. Lefebvre bu çatışmaları şöyle sıralar:

-Kullanım değeri ile değişim değeri arasındaki çatışma,

-Para ve değerli kâğıt olarak servetin seferber edilmesi ile şehre yapılan üretken olmayan yatırım arasındaki çatışma,

-Sermaye birikimi ile sermayenin şenliklerde israfı arasındaki çatışma,

-Egemen olunan toprakların genişlemesi ile egemen şehrin etrafinda bu toprakların katı bir şekilde örgütlenme gerekliliği arasında çatışma (Lefebvre, 2016: 21-24).

Çoğu yazarın paylaştı̆̆ gibi, 19.yy'ın son çeyreğinde gerçekleşen komün ve ardı sıra gelen deneyimlerin öncesinde henüz ilk çeyrekte, İngiltere'de yoğun endüstri devrimi ile birlikte kent sorunları zaten belirgin hale gelmiş ve Glasgow ve Birmingham kentlerinde bu sorunların çözümü adına önemli adımlar atılmıştı. Bumin, yukarıda bahsedilen eski-yeni çatışmasının bu dönemde burjuvazi tarafından aşıldığını ve nihayet endüstriyel kapitalizm için kentin şimdiye kadar görülmemiş bir biçimde yalnızca kar aracıyla el koyduğu bir alana dönüşmesi sürecinin başlatıldığını ayrıntılı olarak ifade eder. Bu galibiyetle birlikte, burjuvazi istediği yeri seçip istediği biçimde fabrika ve konut kurabilir, insanları istediği gibi çalıştırıp, istediği gibi barındırabilirdi (Bumin, 2016: 67).

Fakat yaşanan dönüşüm ile birlikte kentlere yönelen yoğun göç, burjuvazi açısından işlerin tam olarak onların istediği gibi gitmeyeceğinin habercisi gibidir. 19.yy'ın hemen başında yaşanan bu hızlı dönüşüm, yoğun endüstrileşme ve daha fazla artık değer yaratma adına gerek duyulan yoğun emek gücü, kontrolsüzce büyüyen bir nüfus ve bununla bağlantılı olarak önemli konut sorunlarını gündeme getirmiştir. Bayramoğlu durumun tasvirini yaparken özellikle Engels’ten alıntılar yaparak kentlerin o dönemki durumunu çarpıcı bir şekilde anlatır, sanayi devriminin etkisi ile hızla proleterleşen mülksüzlerin; işçilerin, yedek sanayi ordusu üyelerinin, hırsızların doluştuğu kentlerde yaşamı sürdürebilmek giderek güçleşiyordu. Bayramoğlu'nun aktardığı gibi, Engels "İngiltere'de Emekçi Sınıfların Durumu" kitabında gündelik hayatın fotoğrafını şöyle çekmiştir: "Üç-dört oda bir mutfak olan bu evler, Londra'nın bazı kesimleri hariç tüm İngiltere'de bir baştan öteki uca işçi sınıfi evidir. Sokaklarda genelde kaldırım yoktur, inişli yokuşlu, pis, çöp ve hayvan pisliği doludur; kanalizasyon ya da atık su kanalı yoktur... Her yanda çöp ve kül yığınları vardır; kapıların önüne dökülen sıvı atıklar, çok kötü kokular yayan birikintiler halinde durur.” (Bayramoğlu, 2015: 28). 
Tüm bu problemler ve bu problemlerin çözümü adına ilk adımların İngiltere'de atılmış olması gayet anlaşılabilir bir durumdur. Bayramoğlu'na göre, kapitalizmin "sağlıklı" emek gücüne ihtiyaç duyması buna rağmen sağlıksız kentlerde artan salgın hastalıkları ve yoğun bebek ölümleri üstelik şehirlerin burjuvalar için artık "tekinsiz" hale gelmesi adli vakaların artması hem merkezi düzeyde hem de yerelde bazı önlemleri kaçınılmaz kılmıştır. Örneğin Glasgow'da, 1832-1848 yılları arasında görülen kolera salgını, kentte çok hızlı bir şekilde yayılmış ve her sınıftan insanı tehdit etmiştir. Bunun üzerine 1855 y1lında su hizmeti belediyeleştirilmiş ve devam eden dönemde 1869 yılında gaz, 1872 'de ulaşım ve nihayet 1890 'da ulaşım da belediyeleştirilmiştir. Kent adına elde edilen bu kazanımları diğer kentler de takip etmiş, Manchester, Leeds, Liverpool'da da suyun belediyeler tarafından sağlanması için büyük mücadeleler yürütülmüştür (Bayramoğlu, 2015:33-35).

Şunu belirtmek gerekir ki, elde edilen kazanımlar ve toplumcu belediyeciliğin ilk nüveleri sadece yerelde veya merkezdeki bürokrasinin zorunluluğu ile atılmamış, arka planında fabrikalarda çalışan ve oldukça kötü koşullarda yaşamlarını sürdüren işçi sınıfının çabaları ile gerçekleşmiştir.

İngiltere'den başlayıp tüm kıta Avrupa'sına yayılan bu talepler son nokta olarak kendini Paris Komününden bulmuş ve önceden de değinildiği gibi günümüzün Toplumcu Belediyecilik anlayışına birçok referans sunmuştur. Bunları Güler şöyle özetler:

-Paris Komününde krize neden olan konut ve arsa üretimi.

-Kırdan gelenler için oluşturulmaya çalışılan siyasi ve kent kültürü çalışmaları toplumcu belediyecilikte "Kent Enstitüleri" olarak karşıllk bulmuştur

-Paris Komününde ortaya çıkan yerel yönetimlerin siyasallaşması

-Komün demokrasisinin ortaya çıkardığı yerel özgürlük düşüncesi

-Kentsel rantların topluma kazandırılması adına kamulaştırma

-Kırsal bölgelerden gelen niteliksiz iş gücüne beceri kazandırmaya yönelik eğitim olanaklarının geliştirilmesi ve iş imkânlarının yaratılması

-Komünün hedeflerinden olan fakat Komünün ömrünün kısa olması nedeniyle gerçekleştirilemeyen komünler arası birlik, toplumcu belediyecilik anlayışında belediye birliklerini doğurmuştur (Güler, 2013: 127-128).

\subsection{Hareketinin Kent Talepleri}

Toplumcu belediyeciliğe zemin hazırlayan başka bir şey, Lefebre (2016)'1n ifade ettiği gibi, kentte özgürlük ve "kent hakkı" olarak da kavramsallaştırılabilecek ve devletin kent ve kentli üzerindeki özellikle mekânsal yönlendiriciliğini ve tahakkümcü mekanizmalarını protesto amaçlı bir süreç olan 68 hareketidir. 2. Dünya savaşı sonrası yaşanan yıkım, beraberinde farklı bir ekonomik paradigma ile birlikte devletin, hayatın her alanında ve ekonomide aktif olarak yer almasına zemin hazırlamış ve yaratılan zenginleşme ile birlikte, "refah devleti uygulamaları kentin de her kılcalında" kendini hissettirmiştir. Batıda yerel yönetim merkezi devlet ile uyumlu olarak refahın kente dağıtılmasında aracı olarak kendinin konumlamıştır. Fakat 1960'ların ortalarından sonra, var olan Fordist üretim tarzı ve refah devleti uygulamaları krize girmeye ve eleştirilmeye başlanmıştır. Temelde eleştirilen nokta, Fordist üretim biçiminin kendi iç çelişkileri ve dünyanın genel konjonktürü bağlamıdır. Saklı benzer bir yaklaşımla, Fordizmin iç çelişkisinin tek kelimelik ifadesinin "sertlik" (rigity) olduğunu, yani esneksizlik durumunun değişen tüketici taleplerine karşıllk veremediğini belirtir. Saklı yine, kitlesel üretim yapan işletmelerin ve emeğin niteliğinin değişen durumlara ve taleplere karşı yeterli tepkiyi veremediğini ve bundan kaynaklı olarak esnekliğe sahip işletmelerin rekabette ön plana çıkmasının, Fordist üretim yapan işletmeleri dar 
boğaza soktuğuna vurgu yapar (Sakl1, 2007: 7). İşletme temelli bu yaklaşımlara ek olarak daha makro durumların krizi tetiklediği gerçeği ortadadır. Aslına bakılırsa Keyder ve Buğra'nın da ifade ettiği gibi, krizin nedenleri krizi araştıran uzman sayısı kadar çoktur. Fakat onların da katıldığı üzere temelde üç neden vardır: Birincisi; market distortion olarak tanımlanan ve refah devletinin piyasayı boğduğu ve çalışma, tasarruf etme, yatırım yapma gibi ekonomik dürtülerin aşındırıldığını vurgulayan piyasa koşullarından sapmadır. İkincisi; Nüfusun yaşlanmasının uzun süreli dramatik sonuçlarına odaklanan yaklaşımdır. Üçüncüsü; savurgan hükümetleri ve rekabetçi olmayan işletmeleri zorlayan yeni küresel ekonominin sonuçlarını merkeze koyan yaklaşımlardır (Buğra ve Keyder, 2008: 56). Tüm bunların yanı sıra, küreselleşme olgusu bu dönemde yeni yeni dolaşıma girip dönüşümün temel eksenini oluştur. Küreselleşme kavramının tartışıldığ 1 bu dönem, rekabetçi firmaların yüceltildiği ve refah devleti kazanımlarının da yok sayılmaya çalışıldığı dolayısıyla hemen her şeyin yeniden tarif edildiği bir dönem olmuştur. Tüm bunların arka planında epistemolojik olarak da ciddi tartışmalar sürüyor, bu tartışmalar en özünde modernite-postmodernite eksenli devam ediyordu. Özellikle yeni muhafazakârların ve Fransa'da ortaya çıkan post-yapısalcı akımın eleştirileri entelektüel sahada ciddi karşılık buluyordu. Eleştirinin odağında zaten batı felsefesinde ciddi yeri olan amaçsal aklın bu üretim biçimi ile en somut halini aldığı ve en üstte duran yönlendirici aklın emrettiği, bireylerin de bunu yapmakla mükellef olduğu, bireyi ve farklılıkları yok eden yapısıydı. Özellikle Fordist üretim biçiminin çalışanı nesneleştirerek bir makine çarkına dönüştürmesi, katı bürokrasinin egemen olduğu yönetim modellerinin neredeyse faşizmle eşitlendiği bu eleştiriler, post-fordizmin icracıları tarafından da olabildiğince kullanılıyordu. Gerçekten de savaş sonrası yıkımın üstesinden gelmenin yolu sadece işliklerin yeniden üretilmesi-disipline edilmesi ya da çalışma saatlerinin sıkı regülasyonu ile değil aynı zamanda Harvey'in (Harvey, 2003:149) değindiği gibi "yeni insan" yaratmak yolu ile gerçekleşecekti. Bunun formülü sık1 standardizasyondu. Bu standardizasyonu Dikmen kitabında oldukça geniş bir şekilde tartışmıştır, özetle; bunlardan ilki aklın standardizasyonudur. Burada anlatılan, inceleyen, ölçen, araştıran daha iyisini ve hızlısını daha az enerji ve verimlilikle çalışan aklın hayatın merkezine yerleştirilmesidir. Yönetim literatüründen bakarsak, verimlilik arayışının yönetsel etkinliğin merkezine konmasıdır. Felsefik ifade ile dünyaya da kendi dışında her şeye nesne gözüyle bakmaktır. İkinci standardizasyon aşaması zamandır. Göreli olan zaman, mekanik saatin icadı ile beraber eşit aralıklara bölünerek standartlaştırıldı. Saatin toplumsal yaşam üzerindeki etkisi sanayi devrimi ve makineleşme ile ortaya çıktığını biliyoruz. Yaşamı eşit parçalara bölüp bu parçalardan her birinden aynı yoğunlukta yararlanma çabası, insanı, geceleri gündüze çevirmeye zorlamakta ve yapılan işi gece vardiyasına taşımaktadır. Modern iş anlayışı, Dikmen'e göre, aslında kronometrenin zaferidir. Üçüncü standardizasyon mekânın standardizasyonudur. Sanayi devrimi sonrası yaşama alanlarıyla çalışma alanları birbirinden ayrılmış, büyük kentler yeniden inşa edilmiştir. İşyerlerinde iç mekân tasarımı en ince ayrıntısına kadar hesaplanmış, alet, makine ve çalışma alanlarının, insanların en verimli çalışabileceği şekilde düzenlenmesi için istihdam edilmiştir (Dikmen, 2015: 97-104).

$\mathrm{Bu}$ gerçek, yani yaşamın her alanında kendini gösteren standardizasyonun, kapitalizmle ilişkisini kurmak kaçınılmazdır. Fakat bu ilişki sadece kapitalizmi icra edenlere has bir şey değildir. Dönemin kıta Avrupa'sında bunun üzerine çalışan, deşifre eden ve nihayetinde kitleleri yönlendiren muhalif düşünürler oldukça fazla ve etkindir. Harvey bunun için özellikle Lefebvre'den yararlanarak şunu iddia eder: "Parasal ekonomilerde ve özelde kapitalizmde, para zaman ve mekân üzerinde, birbirleriyle kesişen hâkimiyet, toplumsal iktidarın görmezlikten gelemeyeceğimiz bir özsel bağlantısını oluşturur." Harvey şunu ekler; "Bu üçlünün anlamlarını tanımlayanlar aslında toplumsal oyunun temel kurallarını da tanımlar" (Harvey, 2003: 255).

Özetle kapitalizmin yaptığı şey; kendi zaman ve mekân algısını ve kendi kentini ötekilere de dayatmaktır. Bu dayatma sadece modern iktisadi bir çıkar-olgu değil aynı zamanda bir estetik dayatmasıdır. Bahsedilen standardizasyon, 60'ların ortalarından itibaren her mecrada eleştirilmiş ve şehir ile ilgili toplumsal-muhalif pratiklere zemin olmuştur. $\mathrm{Bu}$ tek tipleştirici döngü merkezli 
modernite eleştirisinin, siyaset literatürüne kazandırdığı epistemolojik zenginlik 68'ile birlikte sokakta da karşılığını buluyor ve yine Harvey'in ifadesiyle "bu büyük sıkıcılık afeti” yerini çoklu toplumsal gruplara bırakıyordu. Sınıf siyaseti adına görmezden gelinmiş kimlikler (kadınlar, ögrenciler, siyahlar, çevreciler vs.) toplumsal örgütlenmenin birer öğesi olarak kamusal alanda yerlerini alıyorlardı. Fakat tüm bu farklı toplumsal formasyonların dile gelmesine rağmen yine de dönemin itici gücü işçi sınıfıdır. İşçi sınıfının bu rolünü Lefebvre şöyle anlatır: "Şehir bilimi üzerine temellenen kentsel stratejinin etkili olabilmesi için toplumsal bir dayanağa ve politik güçlere ihtiyaç duyar. Kendi başına harekete geçemez. Esasen kendisine karşı yönelen bu ayrımcıllğa son verebilecek güç olan işçi sınıfının varlığına ve eylemlerine yaslanmadan edemez..." Bu, şu anlama gelir, işçi sınıfi kent toplumunu tek başına yaratamaz belki fakat işçi sınıfi olmadan da hiçbir şey mümkün değildir (Lefebvre, 2016: 127-128).

1968 hareketi ile kapitalizmin, kenti biçimlendiren, düzenleyen ve çoğulculuktan uzak monizmi ile kendi zaman-mekân algısını dayatan hali geniş ölçekte protesto edildi. Bu eylemelerde mekân işgalleri önemli idi. Kapitalizmin mekânları işgal edilerek "tıkır tıkır işleyen kapitalist döngü" sekteye uğratılıyor ve bu mekânlarda eylemciler kendi "zamanlarını" yaşıyorlardı. Bu toplu karşı çııışın en çarpıcı ifadesi ve ülküsü Foucault'un Heterotopia kavramı ile açılımlanır. Harvey’in aktardığı gibi Foucault bu kavramla, "Çok sayıda bölük pörçük olanaklı Dünya'nın, olanaksız bir mekânda" bir arada var olma çabasını ya da ortak olarak ölçülemeyeceği halde birbiriyle bir araya getirilmiş mekânları anlatır. "Karakterler bu yeni dünyada ne yapacaklarını düşünüp eskiyle bağlarını koparmaya çalışırlar” (Harvey, 2003: 64).

Sonuçta bu dönemde hem iktisadi olarak yaşanan darboğaz, azalan gelirler ve kamu harcamaları, şirketler açısından stokların eritilememesi hem özel sektör hem de fabrikalarda, işçi haklarında yaşanan gerileme, emperyalist savaş politikalarının tekrardan dünyanın gündemine gelmesi, kentte yaşanan sıkışmışlık hissi ile birleşince toplumsal hareketler kaçınılmaz olmuştur.

\section{Türkiye'de Kentleşme ve Toplumcu Belediyecilik: Chp Örneği}

Türkiye'de kentleşme olgusunun tartış1lış süreci, birkaç basamak ve evrimsel dönüşümle gerçekleşir. Özellikle 2. Dünya savaşı sonrası yaşanan kırdan kente göç 1950'lerin ortalarından itibaren yoğunlaşmış ve mevcut iktisadi ve kentsel altyapı bu göçü tolere etmekte zorlanmıştır. Üstelik mevcut siyasi-teorik iklimde kent sorunun üzerine düşünecek çözüm üretecek bir yapıda değildir. Tekeli bu durumu kitabında şöyle tartışmıştır; ilk başlarda, yani göç olgusuyla ve kente getirdiği sorunlarla ilk yüzleşildiği zamanlarda, genel olarak bakış negatifti. Köylerinden çıkıp kente gelen ve burada yasadışı gece kondular yapan bu kişiler suç işlemelerinin yanı sıra kent yaşamına adapte olamıyor ve kent dokusunu bozuyorlardı. Dolayısıyla bu kişilerin bir şekilde köylerine dönmeleri sağlanmalıydı. Fakat bu bakış açısı sorunları çözmüyor ve 10. kez yıkılan gecekondu 11. kez tekrar yapılıyordu. 2. Aşamada artık meselenin denetim altına alınabilmesi için yeni kavramsallaştırmaların gerekliliği ortaya çıktı. Bu tartışmalar sonuçta, kırın bir nevi cazibesini artırmak ve üretim düzenini değiştirmek ile kırdan göçün azalacağı noktasında sabitlendi. Fakat bu yaklaşımda kapitalistleşen ülkenin ucuz iş gücü gereksinimini 1skalayarak, birincinin ötesine geçemiyordu. Sonuç olarak göç meselesinin aslında, genelde çevre ülkelerde, özelde Türkiye'de, kalkınma sürecinin bir sonucu olduğu ve sonraları oluşan, gelenleri kabullenme ve kentli kültüre birkaç nesil sonra adapte olacakları fikri beliriyordu. Fakat bu ümidin de boşa çıkması, kentin ve kent kavramının bu ikili kültürel yapı üzerinden algılanması gerçeğini gün yüzüne çıkardı (Tekeli, 2014: 41-44).

Bununla birlikte, köyden kente göç edenler, o dönemin filmlerinde anlatıldığı gibi yanlarına sadece ahşap bir bavul alarak gelmediler. Öncelikli olarak kendilerini yabancı ve yalnız hissetmeyecekleri bir kent oluşmuştu artık. Gelmeden önce kurdukları ilişki ağları ve beraberlerinde getirdikleri küçük sermayeler onları "dövüşe” hazır kılıyordu. Batuman'ın altını çizdiği gibi, göçle gelenleri artık hemşerileri aracılığıyla iş bulma imkânları da vardı. Devlet kentlerde, kaynaklarını 
sanayileşmeye aktarırken, gerekli kentsel hizmetlerin arzını küçük esnaf burjuvalarına bırakarak yeni bir küçük üretici tabakası oluşturuyordu. Dolayısıyla bu tabaka, fabrikalarda çalışan emekçi sınıfının dışında yer alan ve özellikle siyasi partilerin yerel örgütleriyle kurdukları patronaj ilişkileri sayesinde, yerel siyasette ve belediye meclislerinde de önemli bir odak olmuşlardı (Batuman, 2010: 225-226).

Batuman'a göre, göçle gelenler hem bahsedilen kentsel hizmetlerde hem de işgücü olarak fabrikalarda istihdam olanağı buluyorlardı. Üstelik bu patronaj ilişkileri ve gece kondu sorununa siyasilerin oy kaygısıyla görmezlikten gelmesi ve engeller çıkarmaması göç edenleri bir şekilde sistem içinde tuttu. Fakat Bahsedilen döngüyle devam eden süreç, Batuman'ın altını çizdiği gibi 1960 müdahalesiyle ciddi kırılmalar yaratmıştır. Bunlardan birincisi gecekondulardaki patronaj ilişkilerini kesintiye uğratmasıdır. Özellikle askeri rejimin gecekondular için aldığı yıkım kararları gecekondu sakinlerinin yıkımlara karşı direnç oluşturmasına neden olmuş ve dolaylı olarak da merkezi hükümete karşı diğer demokratik talepleri seslendirmelerinde vesile olmuştur. 2. Olgu ise, gecekondu mahallelerinde kurulan ve patronaj ilişkileri ağlarını kuran güzelleştirme derneklerinin kapatılmasıdır. İronik olarak bu dernekler 3 yıl sonra tekrar açıldığında özellikle gece kondularda yaşayan gençlerin buluşma yerlerine dönüşecektir (Batuman, 2010: 228). Darbe koşulları ve ekonomik sıkıntıların, yerelin merkezi bütçeden yeterince pay alamaması sonucunu doğurduğunu da eklemek gerekir. Mesele sadece bütçe yoksunluğu değildir. Aynı zamanda, Türkiye'deki siyasal doğrular ve algılardır. Batıda özellikle 2. Dünya Savaş1 sonrası ortaya çıkan refah devleti uygulamaları, yerele de yansıyor ve hatta yereldeki hizmet ve harcamalar için belediyeler önemli bir aktör haline geliyordu. Şengül, batıda merkezi yönetimle uyum içinde olan, hatta tamamlayıcılık gibi bir misyon edinen yerel yönetimlerin, bizde tam karşıt bir pozisyonda konumlandığını belirtir. Şengül devamında, Türkiye'de yaşanan bu durumun, yani yerel siyasetin bir anlamda merkezi hükümete karşı ve rağmen güçlenmesinin, merkez tarafindan hoş karşılanmaması durumunun, merkezi vesayetin ne kadar güçlü olduğunun bir göstergesi olduğunu belirtir (Şengül, 2009: 172173). Hatta bu yaklaşımın en somut ifadesini 1980 sonrası Fatsa'da Terzi Fikri üzerine demeç veren Kenan Evrende görebiliriz. Bayraktar ve Penpecioğlu'nun aktardığı demeçte Evren oradaki oluşumun özetle, aslında merkezi devlete alternatif olma çabasında olduğunu ve bunun bir anlamda üniterlikle çeliştiğini belirtir (Bayraktar ve Penbecioğlu, 2013: 172). Bu koşullara ek olarak, 1970'lerde yaşanan ekonomik krizin etkilerinin Türkiye'de de derinden hissedilmesi ve bu bağlamda sınıf siyasetinin halk nezlinde giderek artan bir şekilde, karşılık bulması, 1973 genel ve yerel seçimlerinde (Ekim ve Aralık) seçmeni ve yoksul kesimlerin oylarını sola kaydırır. Bu aslında uzun zamandır, CHP'nin beklediği bir fırsattır. Şengül'ün altını çizdiği gibi CHP çok partili sisteme geçtikten sonraki ilk dönemde halkla kucaklaşamamış hem genelde hem de yerel düzeyde gerilemiştir. Dolayısıyla CHP toplumsal tabakasını bu sayede yeniden oluşturacak ve konsolide edecektir. Üstelik CHP'nin en ayırıcı tarafi, gecekondu meselesini sağ partilerden farklı olarak popülist bir oy deposu olarak görmemesidir. Bu sorun onlar için bir sosyal adalet ve vatandaşlık sorunudur (Şengül, 2009: 129-132).

Çevreden merkeze doğru oluşturulan politikalar ve sınıf perspektifinin merkeze alınması sonucu, o güne kadar kentsel sorunlar için kırdan gelenler sorumlu tutulurken, CHP kendi ontolojik gerekçelerine de muhalefet ederek, çoğu sorunun kaynağı olarak kentte yaşayan orta sınıfi işaret eder. Batuman'a göre durum ilginçtir çünkü o güne kadar kentsel yaşantının normu olarak kabul edilen orta sınıfların ve onların yaşam çevreleri ilk kez kentsel sorunların kaynağı olarak kabul edilmiştir. Örneğin; trafik tıkanıklığı, hava kirliliği, su ve kanalizasyon yetersizliği, yüksek kiralar gibi sorunların müsebbibi kente yeni gelenler değil yerleşik orta sınıflardır (Batuman, 2010: 234). $\mathrm{Bu}$ ve benzeri söylemler ile 1973 seçimleri, CHP'nin taşıyıcılığında, toplumcu belediyeciliğin Türkiye siyasetinde en önemli aktör olarak yer aldığ 1 ve kendisini pratik olarak ifade edebileceği bir dönüm noktası olmuştur. CHP bu seçimlerde neredeyse tüm büyükş̧ehir belediyelerini kazandı. Ankara'da Vedat Dalokay, İstanbul'da Ahmet İsvan, İzmir'de İhsan Alyanak, İzmit'te Erol Köse vd. 
Tekeli’ye göre, $\mathrm{Bu}$ süreçte, CHP belediyelerinin yaptı̆̆ en önemli şey, kent yönetiminin demokratikleştirmesini sağlamak oldu. O zaman kadar belli çıkar gruplarının hegemonyasıyla sürüp giden belediyecilik pratiği, toplumcu belediyecilik anlayışıyla ters yüz edildi. Sadece belediye meclislerindeki patronaj ilişkileri değil merkezi yönetimin vesayeti de hafifletilmeye çalışıldı. Belediyelerin standart misyonları olarak görülen "denetleyici", "aracı" ve "pasif" hizmet anlayışından kurtulup "girişimci", "yönlendirici", "üretici" hale geldi ya da bunun için çalışıldı. Tüm bunlarla birlikte belediye tüketimi de düzenlemeliydi. Kentsel tüketim denetlenmeli, kentsel tüketim aracısız, ucuz ve sağlıklı yapılabilmesi için kent ölçeğinde üretim-tüketim kooperatifleri ve tanzim satış ve halk pazarları oluşturuldu. Ayrıca birikmiş kentsel sorunların tek başına bir belediyenin baş etmesi mümkün değildi bunun için be belediyeler dayanışma içinde olmalıydı. Bu da "birlikçilikbütünlükçülük” ilkesinin gereğiydi (Tekeli, 2014: 243-244).

Toplumcu belediyecilik ile ilgili ilkeleri Bayramoğlu şu başlıklar altında özetler:

-Demokratik Belediyecilik: Burada kast edilen karar almanın ötesinde toplumun güçsüz kesimlerinin çıkarlarını koruyucu mekanizmaların kurulmasıdır.

-Üretici Belediyecilik: 3 boyutta tanımlanır, bunların ilki, temel kentsel alt yapı ve hizmet üretimidir. İkincisi, küçük girişimcilerin toplumun büyük kesimleri aleyhine oluşturduğu rantı kırabilmek için piyasa mallarının üretimidir. Son olarak, kent arsalarının değer artışlarının topluma kazandırılması için belediyenin bu alanlara girmesidir.

-Tüketimi Düzenleyici Belediye İlkesi: Ortak mekânlar, alanlar ve olanaklar yaratarak, tüketim yeni bir sosyalleşme biçimine dönüştürülmeli, ucuz tüketim sosyalleşerek sağlanmalıdır.

-Birlikçi-Bütünlükçü Belediyecilik: Toplumcu belediyenin gelişmesi açısından belediyeler arası iş birliği ve dayanışmayı gerekir.

-Kaynak Yaratıcı Belediyecilik: Belediyelerin merkezi yönetimin denetiminde olmayan finans kaynaklarına kavuşmalarıyla ilgilidir. Bunun için kentsel rantın belediyelere aktarılması ve belediyelerin vergilendirmede belirli esnekliklere kavuşturulması gibi yöntemler ileri sürülmüsstür (Bayramoğlu, 2015: 158-161).

CHP belediyeleri bu ilkeler doğrultusunda önemli adımlar attılar. Farklı illerde kâğıt üstünde olan bu ilkeler hayata geçirildi ve halk tarafindan ciddi destek gördü. Fakat bu süreç belediyeler açısından oldukça zorlu ve çatışmalı geçti. CHP'li belediyeler ve aslında belediye başkanları, birçok konuda inisiyatif alarak bu çatışmaların temel öznesi oldu. Bu çatışmaların neler olduğu ile ilgili önemli yazarların tespitleri mevcut. Fakat biz temelde ve genel olarak, bunu üç noktada toparlayabiliriz. İlki önceden de bahsedilen merkezi hükümetle olan çatışmalar. İkincisi belediye meclislerinde yer alan ve patronaj ilişkileri üzerinden rant elde etmeye çalışan gruplar ile olan çatışmalar ve son olarak CHP'nin merkez teşkilatı ile olan çatışmalar. Üçüncü çatışma noktasının sonrasında bu belediye başkanlarının geneli zaten bir daha ki seçimlerde aday gösterilmedi.

\section{Sonuç}

CHP ile yaşanan 73-77 deneyimi bize şunu göstermiştir; doğru yerel politikalar ile halka gidildiği zaman, üstelik tüm yoksunluklara rağmen, bu politikalar halkta mutlaka karşılık bulur. Tüm yoksunluklar ile sadece bütçeyi değil, aynı zamanda o dönem yerel yönetimler için, kuramsal ve pratik birikim anlamındaki her türlü yoksunluğu kastediyoruz. İncelemede görüldügü üzere Avrupa'da 70'lere gelene kadar, belediyecilik ve kent sorunu önemli merhaleler kat etmiş, bunun sayesinde hem teorik hem yönetsel hem de teknik bir birikim oluşmuştur. 1968 hareketi ile birlikte de kent ile ilgili konular, kamu kaynaklarının doğru aktarımının yanı sıra özgürlük sorunsalı odaklı bir zeminde de somut olarak tartışılmış ve kamu otoritelerinin de somut adımlar atmasına neden olmuştur. Fakat bizde kent ve belediyecilik süreci oldukça yenidir. Üstelik dönemin belediyeciliği daha çok şahıslarla anılır dolayısıyla incelediğimiz dönemin kentsel talepleri, Avrupa'nın uzunca bir 
süre önce zaten gerçekleştirdiği fakat bizde henüz gerçekleştirilmemiş taleplerdir. $\mathrm{Bu}$ anlamda, Avrupa'da 1968 hareketinin bizdeki kent taleplerine yansımaları daha çok moral düzeyindedir. Bununla birlikte Türkiye'de temel kentsel ihtiyaçların karşılanması adına pratiğe dönüştürülen bu süreç, özellikle büyük şehirlerde doğru okunmuş ve inkâr edilemeyecek bir biçimde, kamucu belediyeciliğin önündeki en önemli projeksiyonlardan biri olmuştur.

\section{Kaynakça}

Batuman, Bülent, (2010), "Toplumcu Bir Belediyecilik Modeli: "Yeni Belediyecilik Hareketi" 1973-1977”, Mülkiye Dergisi, S:226: 223-241.

Bayraktar, Ulaş, Penpecioğlu, Ergün, (2013), Yerel Yönetimlerde Sosyal Demokrasi Toplumcu Belediyecilik Teorik Yaklaşımlar, Türkiye Uygulamaları içinde "Yerel Liderlik, Toplumcu Belediyecilik ve Ali Dinçer: 1977-1980 Dönemi Ankara Belediyesi”, (Der. İhsan Kamalak ve Hüseyin Gül), İstanbul: Kalkedon Yayınları.

Bayramoğlu, Sonay, Toplumcu Belediye, (2015), Ankara: Nota Bene Yayınevi.

Buğra, Ayşe, Keyder, Çağlar, (2008), Sosyal Politika Yazıları, İstanbul: İletişim Yayınları.

Bumin, Kürşat, (2016), Demokrasi Arayışında Kent, Konya: Çizgi Kitabevi.

Dikmen, Ahmet Alpay, (2015), Makine, İs, Kapitalizm ve İnsan, Ankara: Nota Bene Yayınları.

Güler, Mahmut, (2013), Yerel Yönetimlerde Sosyal Demokrasi Toplumcu Belediyecilik Teorik Yaklaşımlar, Türkiye Uygulamaları içinde "Toplumcu Belediyeciliğin Doğuş Koşulları Üzerine”, (Der. İhsan Kamalak ve Hüseyin Gül), İstanbul: Kalkedon Yayınları.

Harvey, David, (2003), Postmodernliğin Durumu. (Çev. Sungur Savran). İstanbul: Metis Yayınları.

Lefebvre, Henri, (2016), Şehir Hakkı. (Çev. Işık Ergüden). İstanbul: Sel Yayınları.

Şengül, Tarık, (2009), Kentsel Çeliş̧ki Ve Siyaset, Ankara: İmge Yayınevi.

Tekeli, İlhan, (2014), Kent, Kentli Hakları, Kentleşme Ve Kentsel Dönüşüm, İstanbul: Tarih Vakfı Yurt Yayınları.

Habermas, Jürgen, (2017), Kamusallığın Yapısal Dönüşümü. (Çev. Tanıl Bora). İstanbul: İletişim Yayınları.

\section{İnternet Kaynakları}

Sakl1, Ali Rıza, (2007), "Kapitalist Gelişim Sürecinde Fordizm ve Post - Fordizm”, http://2015.ses.org.tr/wp-content/uploads/fordizmpostfordizm.pdf, (Erişim Tarihi: 05.01.2017). 